\title{
Fish feeding and chemical defenses of tropical brown algae in Western Australia
}

\author{
Peter D. Steinberg, Valerie J. Paul \\ School of Biological Sciences A 12, University of Sydney, Sydney, New South Wales 2006, Australia \\ Marine Laboratory, University of Guam, Mangilao, Guam 96923, USA
}

\begin{abstract}
We tested the susceptibility to herbivory of 7 species of tropical brown algae from Bundegi Reef in Exmouth Gulf in Western Australia, and also analyzed these algae for the presence of polyphenolics and other non-polar secondary metabolites. All algae contained very low levels of polyphenolics, consistent with findings from other tropical regions, and the susceptibility of the algae to herbivory was not correlated with the variation in phenolic levels that did exist. Levels of polyphenolics in all these algae were probably too low to have any effect on the herbivores, and polyphenolics may in general play little role in defending tropical algae against herbivores. Five algal species, including the 2 species least favored in our grazing assays, contained other, more lipophilic metabolites. Organic extracts from these 2 species deterred feeding by herbivorous fishes; extracts from other species did not. Our data and previous work suggest that unpalatable tropical brown algae will generally contain low levels of polyphenolics but will contain deterrent, non-polar secondary compounds. The consistently low levels of polyphenolics in tropical brown algae (relative to temperate species) remains a paradox, but may in part be caused by a paucity of trace metals which act as cofactors for biosynthetic systems.
\end{abstract}

\section{INTRODUCTION}

Herbivory on coral reefs is often very intense (Hatcher \& Larkum 1981, Hay 1984, Carpenter 1986, Lewis 1986; review by Gaines \& Lubchenco 1982), and has probably been so for much of the recent evolutionary history of these tropical systems (Steneck 1983, Vermeij 1987). Tropical benthic algae possess a number of mechanisms which minimize the impact of herbivores (Norris \& Fenical 1982, Littler et al. 1983, Hay 1984, Paul \& Hay 1986), many of which likely evolved in response to the intense selective pressure exerted by herbivores, particularly herbivorous fishes (Gaines \& Lubchenco 1982, Hay 1984, Lewis 1986. Littler et al. 1986, Lewis et al. 1987). One of the most important of these mechanisms is the production of secondary metabolites, which can function as chemical defenses against herbivores (reviewed by Hay \& Fenical 1988). A rich array of secondary metabolites has been identified from tropical algae, and many of these compounds deter herbivores from feeding on those algae in the field (Bakus et al. 1986, Hay \& Fenical 1988).

In contrast, although herbivory on benthic macroalgae in temperate systems can also be intense, particularly on rocky reefs (Lawrence 1975, Lubchenco \&
Gaines 1981, Underwood \& Jernakoff 1981, Hawkins \& Hartnoll 1983), the levels and diversity of secondary metabolites found in temperate seaweeds are generally much less than in tropical systems (Fenical 1980, Hay \& Fenical 1988). This latitudinal gradient in the chemical defenses of marine algae parallels other patterns of biogeographical variation in chemical or morphological defenses of marine organisms (Bakus 1964, 1969, Bakus \& Green 1974, Green 1977, Vermeij 1978, Steneck 1986).

The major exception to this tropical/temperate pattern occurs in brown algae (Division Phaeophyta) in the Orders Fucales, Laminariales, and Dictyotales. The first 2 orders often dominate algal communities along temperate rocky shores (Stephenson \& Stephenson 1972. Dayton 1985, Schiel \& Foster 1986) and the Dictyotales are also common in (mostly warm) temperate areas. Most species of temperate Fucales, and some Laminariales and Dictyotales, contain high levels of polyphloroglucinol phenolic compounds (Ragan \& Jensen 1977, Geiselman 1980, Steinberg 1985, 1989, Ragan \& Glombitza 1986), which are perhaps the most important class of algal chemical defense against herbivores in temperate systems (Geiselman \& McConnell 1981, Steinberg 1984, 1985, 1988, Johnson \& Mann 1986, Van Alstyne 1988). 
Paradoxically (given the high intensity of herbivory in the tropics), the common genera of tropical fucoids (such as Sargassum, Turbinaria, and Cystoseira) analyzed so far contain very low levels of polyphenolics (Steinberg 1986, Bird \& Steinberg unpubl., van Alstyne $\&$ Paul unpubl.), much lower than temperate congeners or confamilials (Steinberg 1985, 1986, 1989). Phenolic levels in tropical species of Dictyotales are less well known, but also seem low (van Alstyne \& Paul unpubl.). Kelps (Laminariales) do not occur in warm tropical waters.

In addition to polyphloroglucinols, both temperate and tropical fucoids and dictyotalean algae contain other, mostly non-polar, non-polyphenolic secondary metabolites such as terpenes or prenylated phenolics (Kato et al. 1975, McEnroe et al. 1977. Gerwick \& Fenical 1982, Shizuri et al. 1982, Faulkner 1984, 1986). These compounds are common in tropical species in the Dictyotales, but are either very variable between species (e.g. Sargassum; Faulkner 1984, 1986), or unknown (Turbinaria), in tropical fucoids. It is unclear whether there are overall differences in the production of these compounds between tropical and temperate species in the Fucales or Dictyotales. Some of these metabolites deter feeding by tropical or temperate herbivores (Hay et al. $1987 \mathrm{a}, \mathrm{b}$ ), as do related non-polar compounds from a variety of taxa of algae (Hay \& Fenical 1988). However, many non-polar compounds from algae have no effect on the behavior of herbivores, and even molecules which are structurally very similar can have dramatically different effects on herbivores (Hay \& Fenical. 1988)

These data suggest that polyphenolics are probably too low in tropical brown algae to have an important effect against herbivores, and thus effective chemical defenses should be limited to lipophilic compounds. In this paper we examine the effects that variation in these 2 general classes of secondary metabolites (polyphenolics and lipophilic compounds) have on the interaction between brown algae and tropical fish communities in northwest Australia. We describe the results of feeding experiments, and of assays for both polyphenolics and non-polar secondary metabolites. In addition, because of limited time in Australia, further experiments were done in Guam, in environments with herbivorous fish communities similar to those in northwest Australia.

\section{MATERIALS AND METHODS}

Study sites and organisms. Most collections of algae, and the fish feeding experiments in Australia, were done at Bundegi Reef, a series of patch reefs in the northern end of Exmouth Gulf in northwest Australia $\left(22^{\circ} 21^{\prime} \mathrm{S}, 114^{\circ} 10^{\prime} \mathrm{E}\right)$. This reef is described in more detail in May et al. (1983). A.lgae were collected from an extensive area of sand and coral rubble situated between the main reef and shore. Feeding experiments were done on the reef proper where herbivorous fishes such as scarids, siganids, and acanthurids were abundant. Additional fish feeding experiments with algal extracts (below), were done in Cocos Lagoon at Guam $\left(13^{\circ} 15^{\prime} \mathrm{N}, 144^{\circ} 45^{\prime} \mathrm{E}_{\text {; }}\right.$ see Paul 1987). Many of the species of herbivorous fishes found at Bundegi Reef also occur at Cocos Lagoon, although the diversity at Cocos Reef is lower (V. J. Paul pers. obs.).

Eight species of brown algae were used in the feeding experiments and/or chemical analyses. These included 4 species in the Dictyotales: Dictyota spiralis, Dictyopteris australis, Lobophora variegata, and an unidentified species of Padina, and 4 species in the Fucales: Cystoseira trinodis and 3 species of Sargassum (these have been designated as sp. 1 to 3 , since there is no reliable guide to the numerous species of Sargassum found in tropical or temperate Australia). Voucher specimens have been placed in the John Ray Herbarium, Department of Botany, University of Sydney.

Chemical analyses. Polyphenolic analyses on frozen specimens of each species of algae were done as in Steinberg $(1986,1989)$. Samples were homogenized and extracted in aqueous methanol, and total phenolic content measured by the Folin-Denis technique (Swain \& Hillis 1959, Ragan \& Jensen 1977).

Analysis of the algae for more lipophilic secondary compounds utilized thin layer chromatography (TLC) and proton NMR spectroscopy. Algae were extracted in 1:1 methylene chloride:methanol, the extracts spotted on silica gel TLC plates, and developed in 2 different solvent systems: $100 \%$ dichloromethane and 1:1 ethyl acetate:hexane. They were then visualized under UV light and by subsequent charring with sulfuric acid (Norris \& Fenical 1985, Paul \& Hay 1986). Proton nuclear magnetic resonance (NMR) spectra were also obtained for all extracts to further confirm the presence or absence of secondary metabolites (Paul \& Hay 1986).

Feeding experiments. Determination of the palatability of difforent algae fo fishes followed the techniques of Hay (1984) and Paul et al. (1987). Pieces of algae were entwined between the strands of $0.5 \mathrm{~m}$ lengths of nylon rope, which were then attached to branches of living coral. The ropes were spread over the reef so that each rope was at least $5 \mathrm{~m}$ away from the next rope. Each rope contained 5 pieces of one species of algae, and there were 5 replicate ropes for each species, distributed haphazardly around the reef. At the end of $3 \mathrm{~h}$ the ropes were collected and the number of pieces completely eaten were scored. Differences in palatability were determined by a singlefactor ANOVA followed by Student-Newman-Keuls 
(SNK) tests. This analysis was modified slightly because all pieces on all 5 replicate ropes of 3 species of algae (Sargassum spp. 1 and 3, Cystoseira trinodis) were completely consumed. Thus there was 0 variance among replicates for these species, making treatment variances within the analysis immediately heteroscedastic. This difficulty was overcome by assuming one piece of algae on one replicate rope for each of these 3 species was not eaten, thereby generating an artificially high variance for the amount eaten of these species. Since this procedure results in an underestimate of the amount consumed of the most palatable algae in our study, it is conservative with respect to the primary hypothesis tested by this experiment, i.e. Are there differences in the amount consumed of the different species of algae?

Feeding experiments using organic extracts of the algae as in Paul (1987) were done at Cocos Lagoon Reef in Guam (lack of time and suitable laboratory facilities prevented our doing these assays in Western Australia). Algae were extracted in 1:1 chloroform: methanol and the resultant organic extracts coated onto blades of Enteromorpha clathratus at a concentration of ca $1 \%$ wet mass ( $4 \%$ dry mass) using diethyl ether as a solvent. These concentrations approximate the natural concentration of the organic extracts in the algae. Control blades were coated with ether only. Four pieces each of treated and control pieces of algae were entwined in nylon ropes which were placed out on the reef in pairs ( $N=12$ to 21 pairs) for periods up to 30 min. The number of pieces eaten of treated and control algae were scored and compared with a Wilcoxon Paired Sample Analysis (Paul 1987).

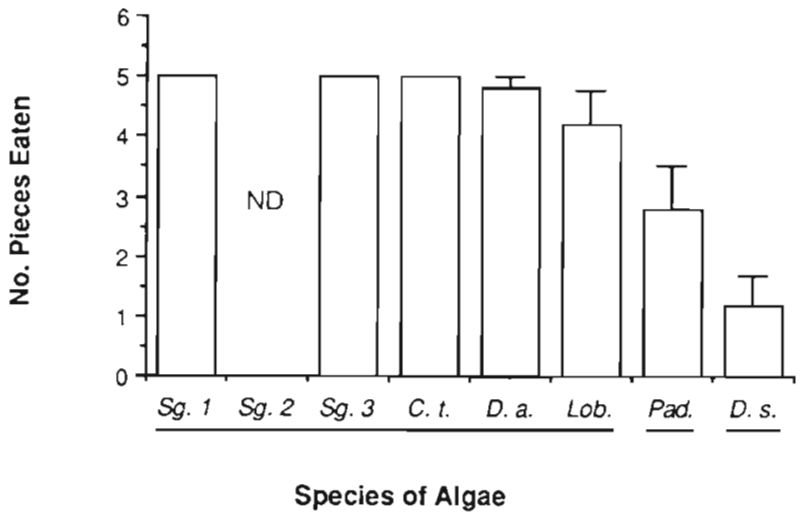

Fig. 1. Consumption of brown algae at Bundegi Reef, Western Australia. Data are number of pieces of algae eaten after $3 \mathrm{~h}$ $(\bar{x}+\mathrm{SE}) . \mathrm{N}=5$ for each species. Species sharing an underline are not significantly different at $p=0.05$ as determined by SNK tests. Key to species of algae used: $\mathrm{Sg} .1$ to 3, Sargassum spp.; C.t., Cystoseira trinodis; D.a., Dictyopteris australis; Lob., Lobophora variegata; Pad., Padina sp.; D.s., Dictyota spiralis. ND: not done

\section{RESULTS}

As determined by a single-factor ANOVA followed by SNK analysis with $\alpha=0.05$, herbivorous fishes at Bundegi Reef in Exmouth Gulf significantly avoided only 2 species of algae, Padina sp. and Dictyota spiralis (Fig. 1). D. spiralis was also consumed significantly less than Padina (Fig. 1). All pieces on all replicates of 3 of 5 species (Sargassum sp. 1 and 3, and Cystoseira trinodis) were consumed, and only one or a few pieces of algae remained on ropes containing Lobophora variegata and Dictyopteris australis. Sargassum sp. 2 was not used in these experiments, in order to keep the number of ropes down to a manageable level.

Phenolic levels, as measured by the Folin-Denis assay, varied significantly among the algae (Fig. 2; single-factor ANOVA on $\ln (\mathrm{x})$ transformed data, $\mathrm{F}_{7,32}=$ 4.065, $p<0.005$ ). However, mean levels of phenolics in all algae were quite low (all $<2 \%$ by dry wt.), comparable to levels contained in palatable brown algae in other studies (Steinberg 1985). Exceptions to this general pattern were one individual each of Dictyopteris australis and Lobophora variegata, each of which contained $>3 \%$ total phenolics.

A comparison of Figs. 1 and 2 shows no correlation between algal phenolic levels and consumption of the algae. For example, the least preferred species, Dictyota spiralis, also contained the lowest level of polyphenolics.

Five of the algae, Sargassum sp. 3, Lobophora variegata, Dictyopteris australis, Padina sp., and Dictyota spiralis also contained additional non-polyphenolic, non-polar secondary metabolites, as indicated by TLC and proton NMR analyses (Fig. 2). L. variegata and

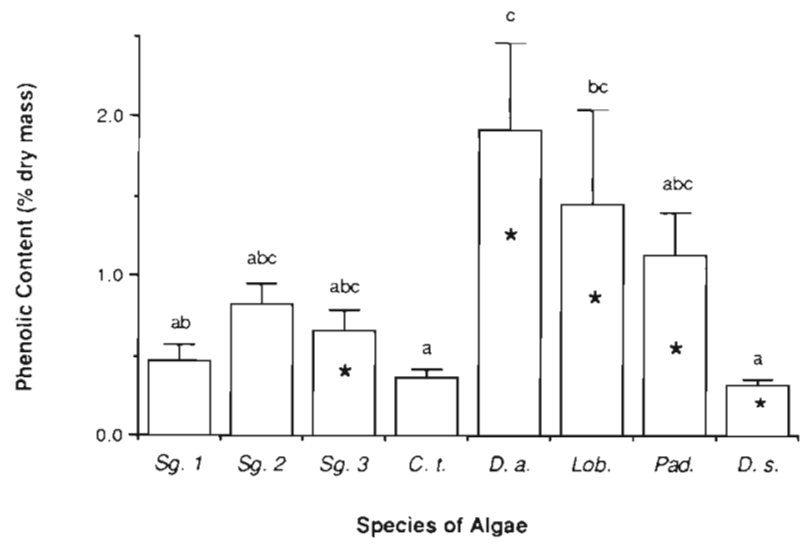

Fig. 2. Secondary chemistry of brown algae from Bundegi Reef. Data are $\bar{x}+$ SE Folin-Denis phenolics ( $\%$ dry mass). $N=$ 5 for each species. Species sharing a letter $(a, b$ or $c)$ do not differ significantly in phenolic content at $p=0.05$, as determined by SNK tests. Species marked with a star contain additional non-polar secondary metabolites, as indicated by TLC and proton NMR (see text) 


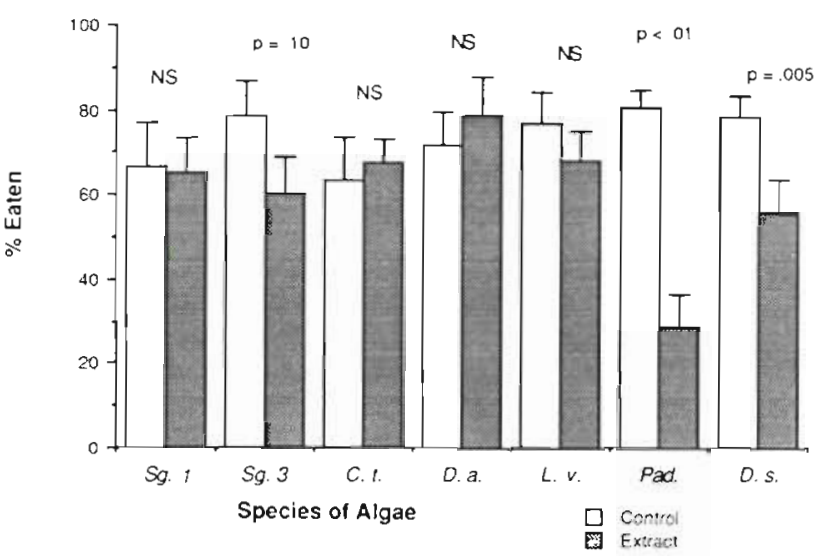

Fig. 3. Effects of non-polar extracts of Bundegi Reef algae on feeding by herbivorous fishes at Cocos Lagoon Reef, Guam. Methods as in Paul (1987). Data are $\bar{x}+$ SE. N (number of pairs of ropes) varied between 12 and 21, depending on the species. Significance determined by a Wilcoxon Paired Sample Analysis. NS: not significant

$D$. australis both contained non-polar hydrocarbons, and the extract from $D$, australis had a highly fragrant odor suggesting the presence of C-11 hydrocarbons well known from this genus (Moore 1978. Hay et al. 1988b). TLC of $D$. spiralis revealed several purplestaining spots similar to those produced by dictyolditerpenoids. Extracts of Sargassum sp. 3 contained non-UV active metabolites in the polarity range of sterols. Padina sp. contained compounds appearing as somewhat polar spots on TLC.

The effects of the organic extracts containing these non-polar compounds on feeding by fishes were tested by examining the deterrent effects of chloroform: methanol extracts against herbivorous fishes in Guam. Extracts from only 2 algae, Dictyota spiralis and Padina sp., significantly deterred feeding by fishes in Guam (Fig. 3). These 2 algae were also the least preferred in the experiments at Bundegi (Fig. 1). These results are consistent with the hypothesis that the unpalatability of these algae is due to the presence (confirmed by TLC) of non-polar, non-polyphenolic secondary metabolites.

\section{DISCUSSION}

The levels of polyphenolics produced by all 8 species of brown algae examined in this study were generally quite low, comparable to those found in palatable, phenolic poor species of temperate brown algae (Anderson \& Velimirov 1982, Steinberg 1985). Although the effectiveness of algal polyphenolics as deterrents against these tropical herbivores was not directly tested (e.g. Geiselman \& McConnell 1981. Steinberg 1988), and individual plants (one each of Dictyopteris australis and Lobophora variegata) occasionally contained slightly higher levels of phenolics, the amounts of polyphenolics generally present in these algae are probably not high enough to deter herbivores. Moreover, there is no correlation between palatability and the (significant) variation in phenolic levels that does exist (Fig. 2), unlike the patterns commonly observed in temperate studies (Steinberg 1984, 1985, Johnson \& Mann 1986). Thus polyphenolics, probably the most abundant and important chemical defense against herbivores in temperate algae, seem to be irrelevant to these tropical plant/herbivore interactions.

Other more non-polar secondary metabolites appear to play a defensive role, as has been found for other tropical brown aigae (Hay et al. 1987a, Paul 1987). However, as might be expected by the results of McConnell et al. (1982) and Hay et al. (1987b), not all of the algal extracts deterred feeding by fishes at Cocos Lagoon, supporting the idea that we should expect considerable variation in the effects of different lipophilic algal metabolites on marine herbivores (Hay \& Fenical 1988). Extracts from the 2 most unpalatable algae in this study were both deterrent, and both contained non-polar secondary metabolites as indicated by TLC (possibly dictyol diterpenoids in the case of Dictyota spiralis). Other, more palatable species from Bundegi Reef (Lobopora variegata, Dictyopteris australis, and Sargassum sp. 3) also contained lipophilic secondary metabolites. However, organic extracts containing these compounds had no effect on feeding by fishes in Guam.

Although our assays with algal extracts were not done at the same place as our other experiments, we feel that these assays are still an important measure of the deterrent effects of the extracts. Many of the same species of fish occur at both Bundegi Reef and Cocos Lagoon (V. J. Paul pers. obs.), and many of the algae co-occur as well (Wylie \& Paul 1988) Moreover, although variation in the effects on fishes of slightly different secondary metabolites is well known (Hay \& Fenical 1988), we know of no instance where different individuals of the same species of fish (or closely related fish) respond differently to the same secondary metabolite. Thus our results showing deterrence of herbivorous reef fishes in Cocos Lagoon by algal extracts seem relevant to the system at Bundegi Reef.

We would generally predict a strong correlation between unpalatability of brown algae in the tropics and the presence of non-polar secondary compounds such as terpenoids or prenylated phenolics. Increasingly, it seems that polyphenolic levels in tropical algae are too low to function as deterrents. The morphology of these relatively tough, fleshy algae probably inhibits feeding by many fishes with relatively delicate jaw morphologies such as Pomacentrids, but does not appear particularly effective against more robust herbivores such as Acanthurids, Scarids, Siganids, or Kyphosids 
(Lewis 1985, 1986). Moreover, among tropical brown algae, only some Padina spp. are calcified, unlike many common red and green seaweeds. Nutritional aspects of algae may influence food choice of herbivorous fishes among major groups of algae (Montgomery \& Gerking 1980), but are not obviously linked to choices among different species within the Dictyotales or Fucales. Thus the responses of tropical brown algae to herbivores would seem limited either to escapes in space or time, rapid growth - none of which would necessarily confer unpalatability - or to the production of non-polar secondary compounds.

We emphasize that this reasoning is based on the interaction between algae and herbivorous fishes; the responses of other types of herbivores such as amphipods or other small 'mesograzers' may well differ from the pattern observed here (Hay et al. 1987b, 1988a, b, Paul et al. 1987)

The low levels of polyphenolics produced by tropical fucoids and Dictyotales remain something of a paradox. One possibile explanation is that tropical herbivorous fishes are not generally deterred by polyphenolics. This is supported by the work of Steinberg et al. (unpubl.), who showed that fishes on the Great Barrier Reef, Australia, did not preferentially consume phenolicpoor tropical species of Sargassum over phenolic-rich temperate Sargassum spp. However, van Alstyne \& Paul (unpubl.) have shown, in experiments similar to those used in this study, that aqueous methanol extracts from species of temperate, phenolic-rich brown algae deterred feeding by fishes in Guam, whereas extracts of phenolic-poor species did not, indicating deterrence of these fishes by polyphenolics. Some temperate herbivorous fishes appear to be deterred from feeding on phenolic-rich species, at least as judged by the diets of fishes such as opaleye Girella nigricans and halfmoon Medialuna californiensis in California, USA, which appear to eat only phenolicpoor species (Quast 1968). However, other temperate herbivorous fishes, such as Odax pullus in New Zealand, feed largely on phenolic-rich brown algae (Clements 1985). Thus a number of tropical and temperate herbivorous fishes appear to be able to cope with a diet rich in polyphenolics.

Alternative suggested explanations (Van Alstyne \& Paul unpubl.) for the failure of tropical brown algae to produce high levels of phenolics center around physiological constraints or costs. However, since polyphenolics may not be any more expensive for the plant to produce than other secondary metabolites (Fox 1981), and are also quite stable compounds, it is difficult to understand why non-polar metabolites, but not polyphenolics, are produced so commonly by tropical algae. In fact, most current theories which relate the 'cost' of secondary compound production to environ- mental factors such as nutrient or light levels (Bryant et al. 1983, Coley et al. 1985) predict that production of carbon-based secondary metabolites should be highest in areas of high light intensity, low nutrients, and high grazing - exactly the conditions on most tropical reefs.

One hypothesis (Steinberg et al. unpubl.), not generally considered, is the possibility that polyphenolic production in tropical algae is limited by the availability of divalent metal ions which are required for the biosynthesis of polyphenolics (Mayer \& Harel 1979). These metals act as cofactors for enzymes such as polyphenol oxidase, and if tropical waters and tropical algae were deficient in these trace metals, then production of polyphenolics would be constrained.

Whatever the underlying mechanisms, patterns are emerging in the interactions between the secondary metabolites of brown algae and large mobile, herbivores such as fishes, sea urchins, and gastropods (Steinberg 1985, 1986, 1989, Hay 1987a, b, Estes \& Steinberg 1988, Van Alstyne \& Paul unpubl.). Polyphenolics are abundant in temperate brown algae, and are effective against herbivores in some temperate regions (Geiselman \& McConnell 1981, Anderson \& Velimirov 1982, Steinberg 1984, 1985, 1988, Johnson \& Mann 1986, Van Alstyne 1988), but are much less effective in other temperate systems (Steinberg 1989, Steinberg \& Van Altena unpubl.). Polyphenolics are probably unimportant as defenses in tropical brown algae. Non-polar metabolites such as terpenes and prenylated aromatics are found both in temperate, and, perhaps more commonly (Pathirana \& Anderson 1984), in tropical algae, and some, but not all of these compounds are deterrent against herbivores (Hay et al. $1987 \mathrm{a}$, b, this paper).

Thus the importance of different chemical defenses in brown algae depends on where they are studied, what herbivores are studied (Hay et al. 1988a, b), and often the specific structure of each molecule. Although the 2 major groups of defensive compounds in brown algae are in some ways analogous to the dichotomy erected for terrestrial plants of 'toxins' vs tannins or polyphenols (Feeny 1976, Rhoades \& Cates 1976), consistent generalizations about the ecological effects of these compounds based simply on their gross structural characteristics are not possible (Hay \& Fenical 1988). Both brown algal polyphenolics and lipophilic compounds such as terpenes can act as behavioral deterrents, and we know so little about any other toxic or physiological effects against marine herbivores that no further distinctions can be made. The only obvious similarity between these terrestrial models and patterns in marine algae are that polyphenolics are typically produced in much higher quantities (up to $15 \%$ by dry mass; Ragan \& Glombitza 1986) than are terpenes or other non-polar compounds (rarely $>5 \%$, usually about 
$1 \%$ or less by dry mass). This suggests that the concentration of polyphenolics needed to be effective against herbivores is greater than that for lipophilic compounds in both marine and terrestrial systems.

Acknowledgements. We thank W. Fenical for making the trip to Western Australia possible, and for his support. R. Lethridge and $\mathrm{M}$. Borowitzka assisted with logistics and planning, and P. Farrant helped with algal identifications. Comments from 2 reviewers helped strengthen and clarify the manuscript. Support for this work came from a Queen Elizabeth II Fellowship and a Marine Science and Technologies Grant from the Australian government (P.D.S.) and the National Science Foundation (OCE \# 8600998 to V.J.P.).

\section{LITERATURE CITED}

Anderson, R. J., Velimirov, B. (1982). An experimental investigation of the palatibility of kelp bed algae to the sea urchin Parechinus angulosus. P.S.Z.N.I. Mar. Ecol. 3: 357-373

Bakus, G. J. (1964). The effects of fish-grazing on invertebrate evolution in shallow tropical waters. Occ. Pap. Allan Hancock Fdn 27. 1-29

Bakus, G. J. (1969). Energetics and feeding in shallow marine waters. Int. Rev. gen. exp. Zool. 4: 275-369

Bakus, G. J., Green, G. (1974). Toxicity in sponges and holothurians: a geographic pattern. Science 185: 951-953

Bakus, G. J., Targett, N. M., Schulte, B. (1986). Marine chemical ecology: an overview. J. chem. Ecol. 12: 951-987

Bryant, J. P., Chapin III., F. S., Klein, D. R. (1983). Carbon/ nutrient balance of boreal plants in relation to vertebrate herbivory. Oikos 40: 357-368

Carpenter, R. (1986). Partitioning herbivory and its effects on coral reef algal communities. Ecol. Monogr. 56: 345-63

Clements, K. D. (1985). Feeding in 2 New Zealand herbivorous fish, the butterfish Odax pullus and the marblefish Aplodactylus arctidens. M. Sc. thesis, University of Auckland

Coley, P. D., Bryant, J. P., Chapin III, F. S. (1985). Resource availability and plant antiherbivore defense. Science 230 : 895-899

Dayton, P. K. (1985). Ecology of kelp communities. Ann. Rev. Ecol Syst. 16: 215-245

Estes, J. A., Steinberg, P. D. (1988). Predation, herbivory and kelp evolution. Paleobiology 14: 19-36

Faulkner, D. J. (1984). Marine natural products: metabolites of marine algae and herbivorous marine mollusks. Nat. Product Rep. 1: 251-280

Faulkner, D. J. (1986). Marine natural products. Nat. Product Rep. 3: $1-33$

Feeny, P. P. (1976). Plant apparency and chemical defenses. Recent Adv. Phytochem. 10: 1-42

Fenucal, W. (1980). Distributional and taxonomic features of toxin-producing marine algae. In: Abbott, I. A., Foster, M S., Eklund, L. F. (eds.) Pacific seaweed aquaculture Califomia Sea Grant College Program, Institute of Marine Resources, University of California, La Jolla, p. 144-151

Fox, L. R. (1981). Defense and dynamics in plant-herbivore systems. Am. Zool. 21.85.3-864

Gaines, S. D., Lubchenco, J. (1982), A unified approach to marine plant-herbivore interactions. II, Biogeography. Ann. Rev. Ecol. Syst. 13: 111-138

Geiselman, J A. (1980). Ecology of chemical defenses of algae against the herbivorous snail Littorina littorea, in the New
England rocky intertidal community. Ph. D. disertation, M.I.T., Cambridge

Geiselman, J. A., McConnell, O. J. (1981). Polyphenols in the brown algae Fucus vesiculosus and Ascophyllum nodosum: chemical defenses against the herbivorous snail Littorina littorea. J. chem. Ecol. 7: 1115-1133

Gerwick, W. H., Fenical, W (1982). Icthyotoxic and cytotoxic metabolites of the brown alga, Stypopodium zonale. J. org. Chem. 46: 22-27

Green, G. (1977). Ecology of toxicity in marine sponges. Mar Biol. 40: 207-215

Hatcher, B. G., Larkum, A. W D. (1981). An experimental analysis of factors controlling the standing crop of the epilithic algal community on a coral reef. J. exp. mar. Biol. Ecol. 69: 61-84

Hawkins, S. J., Hartnoll, R. G. (1983) Grazing of intertidal algae by marine invertebrates. Oceanogr. mar. Biol. A. Rev. 21. 195-282

Hay, M. E. (1984). Predictable spatial escapes from herbivory: how do these affect the evolution of herbivore resistance in tropical marine communities? Oecologia (Berl.) 64: 396-407

Hay, M. E., Duffy, M. E., Fenical, W., Gustafason, K. (1988b). Chemical defense in the seaweed Dictyopteris delicatula: differential effects against reef fishes and amphipods. Mar. Ecol. Prog. Ser. 48: 185-192

Hay, M. E., Duffy, J. E., Pfister, C. A., Fenical, W (1987b) Chemical defense against different marine herbivores: are amphipods insect equivalents? Ecology 68: 1567-1580

Hay, M. E., Fenical, W. (1988). Marine plant-herbivore interactions: the ecology of chemical defense. Ann. Rev. Syst. Ecol. 19: 111-145

Hay, M. E., Fenical, W., Gustafason, K. (1987a). Chemical defense against diverse coral-reef herbivores. Ecology 68 : $1581-1592$

Hay, M. E., Renaud, P. E., Fenical, W. (1988a). Large mobile vs. small sedentary herbivores and their resistance to seaweed chemical defenses. Oecologia (Berl.) 75: 246-252

Johnson, C. R., Mann, K. H. (1986). The importance of plant defense abilities to the structure of seaweed communities: the kelp Laminaria longicruis de la Pylaie survives grazing by the snail Lacuna vincta (Montagu) at high population densities. J. exp. mar Biol. Ecol. 97: 231-267

Kato, T., Kurnanireng, A. S., Ichinose, I., Kitihara, Y., Kakinada, Y., Kato, Y (1975). Structure and synthesis of active component from a marine alga. Sargassum tortile, which inhibits the settling of swimming larvae of Coryne uchidai. Chem. Lett. 335-338

Lawrence, J. (1975). On the relationship between marine plants and sea urchins. Oceanogr. mar. Biol. A. Rev. 13: 213-286

Lewis, S. M. (1985). Herbivory on coral reefs: algal susceptibility to herbivorous fishes. Oecologia (Berl.) 65: 370-375

Lewis, S. M. (1986). The role of herbivorous fishes in the organization of a Caribbean reef community. Ecol. Monogr 56: 183-200

Lewis, S. M., Norris, J. N., Searles, R. B. (1987). The regulation of morphological plasticity in tropical reef algae by herbivory. Ecology 68: 636-641

Littler, M. M., Taylor, P. R., Littler, D. S. (1983). Algal resistance to herbivory on a Caribbean barrier reef. Coral Reefs 2: 111-118

Littler, M. M., Taylor, P. R., Littler, D. S. (1986). Plant defense associations in the marine environment. Coral Reefs 5: $63-72$

Lubchenco, J., Gaines, S. D. (1981). A unified approach to marine plant-herbivore interactions. I. Populations and communities. Ann. Rev. Ecol. Syst. 12: 405- 437 
May, R. F., Lenanton, R. C. J., Berry, P. F. (1983). Ningaloo Marine Park report and recommendation by the Marine Park working group. National Parks Authority Report \# 1. Dept National Parks and Wildlife, Crawley, W. Australia

Mayer, A. M., Harel, E. (1979). Polyphenol oxidases in plants. Phytochemistry 18: 193-215

McConnell, O. J., Hughes, P. A., Targett, N. M., Daley, J. (1982). Effects of secondary metabolites on feeding by the sea urchin, Lytechinus variegatus. J. chem. Ecol. 8: $1427-1453$

McEnroe, F. J., Robertson, K. J., Fenical, W. (1977). Diterpenoid synthesis in brown seaweeds in the family Dictyotaceae. In: Faulkner, D. J., Fenical, W (eds.) Marine natural products chemistry. Plenum Press, New York, p. $179-189$

Montgomery, W. L., Gerking, S. D. (1980). Marine macroalgae as food for fishes: an evaluation of potential food quality. Environ. Biol. Fish. 5: 143-153

Moore, R. E. (1978). Algal norisoprenoids. In: Scheuer, P. J (ed.) Marine natural products: chemical and biological perspectives. Academic Press, New York p. 43-124

Norris, J. N., Fenical, W. (1982). Chemical defenses in tropical marine algae. Smithson. Contrib. mar. Sci. 12: 417-431

Norris, J. N., Fenical, W. (1985). Natural products chemistry: uses in ecology and systematics. In: Littler, M. M., Littler, D. S. (eds.) Handbook of phycological methods: ecological field methods, macroalgae. Cambridge University Press, Cambridge, p. 121-145

Pathirana, C., Anderson, R. J. (1984). Diterpenoids from the brown alga Dictyota binghamiae. Can. J. Chem. 62: $1666-1670$

Paul, V. J. (1987). Feeding deterrent effects of algal natural products. Bull. mar. Sci. 41: 514-522

Paul, V J., Hay, M. E. (1986). Seaweed susceptibility to herbivory: chemical and morphological correlates. Mar Ecol. Prog. Ser 33: 255-264

Paul, V. J., Hay, M. E., Duffy, J. E., Fenical, W., Gustafason, K (1987). Chemical defense in the seaweed Ochtodes secundiramea (Montagne) Howe (Rhodophyta): effects of its monoterpenoid components upon diverse coral-reef herbivores. J. exp mar. Biol. Ecol. 114: 249-260

Quast, J. C. (1968). Observations on the food of kelp bed fishes. Calif. Dep. Fish. Game. Fish Bull. 139: 109-142

Ragan, M. A., Jensen, A. (1977). Quantitative studies on brown algal polyphenols. I. Estimation of absolute polyphenol content of Ascophyllum nodosum (L.) and Fucus vesiculosus (L.) J. exp. mar Biol. Ecol. 34: 245-258

Ragan, M. A., Glombitza, K.-W (1986). Phlorotannins, brown algal polyphenols. Prog. phycol. Res. 4: 129-241

Rhoades, D., Cates, R. (1976). Toward a general theory of

This article was presented by Dr P. W. Sammarco, Townsville, Australia plant antiherbivore chemistry. Recent Adv. Phytochem. 10: $168-213$

Schiel, D. R., Foster, M. S. (1986), The structure of subtidal algal stands in temperate waters. Oceanogr mar Biol. A. Rev. 24: 265-308

Shizuri, Y., Matsukawa, S., Ojika, M., Yamada, K. (1982). Two new farnesylacetone derivatives from the brown alga Sargassum micracanthum. Phytochem. 21. 1808-1809

Steinberg, P. D. (1984). Algal chemical defense against herbivores; allocation of phenolic compounds in the kelp Alaria marginata. Science 223: 405-407

Steinberg, P. D. (1985). Feeding preferences of Tegula funebralis and chemical defenses in marine brown algae. Ecol. Monogr. 55: 333-349

Steinberg, P. D. (1986). Chemical defenses and the susceptibility of tropical marine algae to herbivores. Oecologia (Ber1.) 69: 628-630

Steinberg, P. D. (1988). The effects of quantitative and qualitative variation in phenolic compounds on feeding in three species of marine invertebrate herbivores. J. exp. mar Biol. Ecol. 120: 221-237

Steinberg, P. D. (1989). Biogeographical variation in brown algal polyphenolics and other secondary metabolites: comparison between temperate Australasia and North America. Oecologia (Berl.) 78: 373-382

Steneck, R. S. (1983). Escalating herbivory and resulting adaptive trends in calcareous algal crusts. Paleobiology 9: 44-61

Steneck, R. S. (1986). The ecology of coralline algal crusts: convergent patterns and adaptive strategies. Ann. Rev. Ecol. Syst. 17: 273-303

Stephenson, T A., Stephenson, A. (1972). Life between tidemarks on rocky shores. W H. Freeman and Co., San Francisco

Swain, T., Hillis, W E. (1959). The phenolic constituents of Prunus domesticus. I. The quantitative analysis of phenolic constituents. J. Sci. Fd Agric. 10: 63-68

Underwood, A. J., Jernakoff, P. (1981). Effects of interactions between algae and grazing gastropods on the structure of a low shore intertidal algal community. Oecologia (Berl.) 48: $221-223$.

Van Alstyne, K. L. (1988). Herbivore grazing increases polyphenolic defenses in the intertidal brown alga Fucus distichus. Ecology 69: 655-663

Vermeij, G. J. (1978). Biogeography and adaptation. Harvard Press, Cambridge

Vermeij, G. J. (1987). Evolution and escalation. Princeton University Press, Princeton, N. J.

Wylie, C. R., Paul, V. J. (1988). Feeding preferences of the surgeonfish Zebrasoma flavescens in relation to chemical defenses of tropical algae. Mar. Ecol. Prog. Ser. 45: 23-32

Manuscript first received: March 30, 1989

Revised version accepted: August 24, 1989 